\title{
Simultaneous detection of downy mildew and powdery mildew pathogens on Cucumis sativus and other cucurbits using duplex-qPCR and HRM analysis
}

\author{
Kishore Babu Bandamaravuri ${ }^{1,3^{*}} \mathbb{C}$, Ashish K. Nayak ${ }^{3}$, Anu Sharma Bandamaravuri ${ }^{2}$ and Abdul Samad ${ }^{1}$
}

\begin{abstract}
Powdery mildew and downy mildew are two devastating diseases on cucumber and other cucurbit crops caused by Podosphaeraxanthii and Pseudoperonospora cubensis, respectively. Identification and detection of these pathogens from field and plant material could be significant for the selection of resistant varieties and formulation of disease management strategies. In the present study, a duplex qPCR assay developed for simultaneous detection and quantification of both pathogens from different samples. Two sets of species-specific primers developed for the detection of P. xanthii and P. cubensis pathogens by targeting the internal transcribed spacer (ITS) region of the rDNA gene cluster. The specificity of designed primers was also evaluated against the different microbial, plant, soil, and environmental samples. Initially, the individual assays for $P$. cubensis and $P$. xanthii were validated using their corresponding speciesspecific primers, which amplified the prominent and distinctive products of $\sim 705 \mathrm{bp}$ and $\sim 290 \mathrm{bp}$ size, respectively. SYBR green-based duplex real-time PCR assay was developed to detect and quantify both mildew pathogens from different field samples. The species-specific oligonucleotide primer sets showed high specificity with melt curve peaks at $85.83^{\circ} \mathrm{C}$ and $88.05^{\circ} \mathrm{C}$, for P.xanthii and P. cubensis, respectively. The relative quantification and lowest detection limit of qPCR assays using tenfold diluted plasmid (Csp1 and Csd1) DNA were estimated ( $0.1 \mathrm{pg} / \mu \mathrm{ll}$ ) through a standard curve. In this study, the species-specific PCR and qPCR assays in both simplex and duplex formats have been validated successfully. These assays could be useful for efficient detection and quantification of mildew pathogens from the cucumber and other cucurbit crops.
\end{abstract}

Keywords: SYBR green, qPCR, Powdery mildew, Downy mildew, Cucumber

\section{Key points}

- The current study describes the identification and detection of two obligate biotrophic pathogens of cucurbit crops.

- The species-specific PCR assays provided a specific amplification of $\sim 705 \mathrm{bp}$ and $\sim 290 \mathrm{bp}$ products for $P$. cubensis and P. xanthii.
- The HRM analysis indicated that the primer sets were specific and simultaneously discriminated against $P$. cubensis and $P$. xanthii pathogens.

- The species-specific assays could be supportive diagnostic tools for plant pathologists, and plant breeders for detection and discrimination of both powdery mildew and downy mildew pathogens.

\footnotetext{
*Correspondence: kishorebanadam@cimap.res.in

1 Department of Plant Pathology, Crop Protection Division, CSIR-Central

Institute of Medicinal and Aromatic Plants, Lucknow 226015, India

Full list of author information is available at the end of the article
}

\section{Springer Open}

(c) The Author(s) 2020. This article is licensed under a Creative Commons Attribution 4.0 International License, which permits use, sharing, adaptation, distribution and reproduction in any medium or format, as long as you give appropriate credit to the original author(s) and the source, provide a link to the Creative Commons licence, and indicate if changes were made. The images or other third party material in this article are included in the article's Creative Commons licence, unless indicated otherwise in a credit line to the material. If material is not included in the article's Creative Commons licence and your intended use is not permitted by statutory regulation or exceeds the permitted use, you will need to obtain permission directly from the copyright holder. To view a copy of this licence, visit http://creativeco mmons.org/licenses/by/4.0/. 


\section{Introduction}

Cucurbits are one of the most cultivated vegetable crops worldwide, and a large number of annual species are under cultivation in tropical and sub-tropical regions (Judd et al. 2008). In India, the cucurbits are cultivated mainly as food crops, which share about $5.6 \%$ of the total vegetable production. Cucumis sativus (Cucumber) is one of the significant cucurbit crops under cultivation in India, and other cucurbit crops include gourds, melon, and pumpkin. Apart from food and vegetable use, many cucurbits seeds and fruits are reported to have medicinal properties due to the presence of secondary metabolite cucurbitacin (Kaushik et al. 2015). Notably, the fruits of $C$. sativus possess depurative, diuretic, and purgative properties and also used to treat blemished skin and heat rash (Bown 1995; Afari et al. 2012).

More than 200 known pathogens are infecting different cucurbit hosts (Zitter et al. 1996). The major fungal diseases are vascular wilt (Erwinia tracheiphila), gummy stem blight (Mycosphaerella melonis), anthracnose (Colletotrichum orbiculare), powdery mildew (Podosphaera xanthii), alternaria blight (Alternaria cucumerina), and downy mildew (Pseudoperonospora cubensis), (Watson and Napier 2009). Out of all fungal diseases, mildews are widespread and destructive plant diseases caused by obligate biotrophic pathogens, which produce large quantities of short-lived, asexual spores on the surface of host plant leaves. These asexual spores cause secondary infections and disperse through the air to infect fresh plants.

Downy mildew (DM), caused by Pseudoperonospora cubensis (Berk. et Curt.) Rostov., usually occurs in all cucurbit crops such as cucumber, bitter gourd, melons, pumpkin, and ridge gourd grown in open fields, net houses, and home gardens (Lebeda and Cohen 2011; Olczak-Woltman et al. 2011; Holmes et al. 2015). The severity and progress of the disease depend on favorable conditions like high humidity, temperature, light intensity, and source of inoculum. The preliminary symptoms appear on the upper surface of mature leaves as yellow angular spots and chlorotic lesions on the opposite side of the spot. Severely infected plants produce retarded/ deformed fruits, which leads to a considerable loss of production. As the disease progress, the yellow spots became brown and then necrotic, which leads to leaf fall and death.

In the case of powdery mildew (PM) disease of cucurbit crops, two distinctly separate obligate pathogens such as Golovinomyces orontii (Castagne) V.P Heluta, and Podosphaera xanthii (Castagne) U. Braun and N. Shish. (Shishkoff 2000), causing significant economic losses in India and worldwide. Since both the pathogens produce similar symptoms and modes of infection, identification and differentiation of these pathogens become difficult. Though both are different species, morphologically distinct, and even epidemiological variations were reported, their molecular characterization and detection could provide an accurate estimate of each pathogen's distribution and economic impact (Nayak et al. 2019). In early stages, white circular powdery patches on either side of infected leaves and later whole leaf, petiole, stem, and branches of the plant were covered with white powdery spores. Several reports indicated that both mildew diseases were widespread worldwide, particularly in United States, China, Europe, India, and Israel, causing significant production loss in cucurbits (Colucci et al. 2006; Holmes et al. 2015; Lebeda and Urban 2004; Savory et al. 2011; Thomas 1996).

There are several established methods to control/ manage both the mildew diseases such as application of chemical fungicides, the use of resistant or tolerant cultivars, and practicing crop rotation with a non-target host. However, the use of fungicides is not always feasible because of the high cost, and adverse effect on the environment. Moreover, excessive application of fungicides has shown development of resistance in several pathogens towards many chemical compounds (Waard et al. 1993; Hollomon and Wheeler 2002), which necessitates alternative or complementary methods that are effective against mildew pathogens and, reliable to crop ecosystem (Kiss 2003).

Early diagnosis of these infections could be a critical issue in order to implement effective strategies for controlling both mildew diseases (Wyenandt et al. 2015). Since both are caused by obligate pathogens of cucurbits, the possible way to detection of these pathogens could be either by typical disease symptoms or by DNA-based techniques. The conventional classification and identification of both these pathogens have been established (Goker et al. 2003; Waterhouse and Brothers 1981; Sitterly 1978) and molecular identification based on rDNA sequences has also been reported (Wang et al. 2008; Lee et al. 2016). However, due to the obligate nature of both pathogens, rapid and early detection of fungal pathogens in different plant materials and soil has an advantage over mere identification. The species-specific DNA-based molecular tools could be useful for early and accurate detection of plant pathogens (Gachon et al. 2004; Falacy et al. 2007). Therefore, PCR and quantitative real-time PCR (qPCR) based identification and detection of the unculturable fungal pathogens using species-specific oligonucleotides has become the most comprehensive, accurate, and rapid technology (Schenck et al. 2016; Lee et al. 2016). In recent advancements, qPCR has emerged with high resolution melting (HRM) analysis as an alternative to hydrolysis probe chemistry for detection and 
quantification of fungal pathogens (Summers et al. 2015; Lee et al. 2016; Zambounis et al. 2015). The duplex and multiplex PCR utilizes more than one set of primers within a single reaction; each primer set generates a specific size of amplicons, which segregate from other sets through electrophoresis (Chamberlain et al. 1988; Ioos et al. 2012; Bi et al. 2019).

In recent studies, though different specific primer sets of both $P$. cubensis and $P$. xanthii were designed by targeting the ITS region of rDNA (Wang et al. 2008; Lee et al. 2016; Pirondi et al. 2015), these assays were demonstrated separately for each pathogen. Further, the specificity and sensitivity of these assays against other fungi, commonly associated with cucurbit crops, were not determined. Therefore, a robust molecular detection assay to detect and distinguish both $P$. cubensis and $P$. xanthii simultaneously and accurately is of prerequisite. The current study focused on developing an SYBR green-based reliable and sensitive duplex qPCR assay for the identification and simultaneous detection of both pathogens from different samples.

\section{Materials and methods}

\section{Pathogen collection and maintenance}

In the present study, field surveys conducted during the winter season (Oct.-Feb.) in vegetable cultivating fields across different districts of Odisha, India in the year
2014-2015 and different locations nearby Lucknow, Uttar Pradesh, India in 2016-2017. Plant and leaf samples belonging to different cucurbit hosts infected by either powdery mildew or downy mildew diseases were collected (Table 1). The fungal and bacterial cultures used in the present study were also collected from different cropping and agro-forest areas (Table 2). The reference mildew obligate fungal pathogens (cannot be cultured on artificial media) such as $P$. xanthii CsKP07 and $P$. cubensis CsKD11 were established on respective hosts for propagation and maintained under glasshouse. The pathogens P. xanthii CsKP07 and P. cubensis CsKD11infected plant parts were collected for specimen preparation, and voucher specimens were stored at Microbial Germplasm Collection at Department of Plant Pathology, CSIR-CIMAP, Lucknow, India under the accessions MSCsPm180705 and MsCsDm180705 respectively. All other fungal and bacterial cultures used as representative test cultures were maintained on potato dextrose agar and nutrient agar slants until further use.

\section{Sample preparation and genomic DNA extraction}

Powdery and downy mildew pathogen propagules such as conidia and sporangia, respectively were isolated from the corresponding infected living hosts maintained under glasshouse and purified for DNA extraction. Both conidia and sporangia collected into separate bottles containing

Table 1 Powdery mildew and downy mildew infected leaf samples of cucurbits hosts collected from different fields

\begin{tabular}{|c|c|c|c|c|c|}
\hline \multirow[t]{2}{*}{ SI. no. } & \multirow[t]{2}{*}{ Isolate name and code } & \multirow[t]{2}{*}{ Host and place of collection } & \multirow[t]{2}{*}{ Accession no. } & \multicolumn{2}{|c|}{ Different PCR assays } \\
\hline & & & & PxK PCR & PcK PCR \\
\hline 1 & Podosphaera xanthii (RPRCCs08) & Cucumis sativus, Puri & MN630275 & + & - \\
\hline 2 & P.xanthii (CmaKP15) & Cucurbita maxima, Lucknow, UP & NA & + & - \\
\hline 3 & P.xanthii (Mc06) & Momordica charantia, Puri & NA & + & - \\
\hline 4 & P.xanthii (LC10) & Luffa cylindrica, Cuttack & NA & + & - \\
\hline 5 & P.xanthii (LaKPm02) & Luffa acutangula, Keonjar & KY319039 & + & - \\
\hline 6 & P.xanthii (Ls01) & Lagenaria siceraria, Puri & KU376473 & + & - \\
\hline 7 & P.xanthii (CsKP07) & C. sativus, Keonjhar & MN630273 & + & - \\
\hline 8 & P.xanthii (CmKP04) & Cucumis melo, Lucknow, UP & NA & + & - \\
\hline 9 & P.xanthii (LsKP02) & L. siceraria, Lucknow, UP & NA & + & - \\
\hline 10 & P.xanthii (CsKP09) & C. sativus, Lucknow, UP & MN630271 & + & - \\
\hline 11 & Pseudoperonospora cubensis (CsKDM11) & C. sativus, Cuttack & MN630274 & - & + \\
\hline 12 & P. cubensis (RPRCCs04) & C. sativus, Keonjhar & MH458898 & - & + \\
\hline 13 & P. cubensis (LcKDm02) & L. cylindrica, Bhadrak & KU041747 & - & + \\
\hline 14 & P. cubensis (CmKD04) & C. maxima, Puri & NA & - & + \\
\hline 15 & P.cubensis (LC17) & L. cylindrica, Keonjhar & NA & - & + \\
\hline 16 & P. cubensis (LaKDm03) & L. acutangula, Bhadrak & NA & - & + \\
\hline 17 & P. cubensis (CsKD08) & C. sativus, Lucknow, UP & MN630272 & - & + \\
\hline 18 & P. cubensis (LA10) & L. acutangula, Sitapur, UP & NA & - & + \\
\hline 19 & P. cubensis (CM04) & C. maxima, Lucknow, UP & NA & - & + \\
\hline
\end{tabular}

${ }^{a}$ Accession number in Italics are from other studies 
Table 2 The genomic DNA of different microbial isolates used for validation of different species-specific PCR assays

\begin{tabular}{|c|c|c|c|c|}
\hline SI. no. & Isolate name & DNA/isolate code & Host and collection of place & Accession no. $^{a}$ \\
\hline 1 & Fusarium proliferatum & Dr 04 & Dendrobium regium orchid & MF373328 \\
\hline 2 & Colletotrichum crassipes & $\operatorname{Pd} 13$ & Pomatocalpa decipiens orchid root & MF373336 \\
\hline 3 & Penicillium spp. & Ps05 & C. maxima, Puri, Odisha, India & NA \\
\hline 4 & Colletotrichum siamense & CIMAP:Up-72013 & Uraria picta, CIMAP, UP, India & KU925900 \\
\hline 5 & Curvularia pseudobrachyspora & CIMAP: Ac-112017 & Acorus calamus, CIMAP, UP, India & MG645008 \\
\hline 6 & Rhizoctonia solani & AG4 & Plantago, CIMAP, UP, India & KU253632 \\
\hline 7 & Pseudomonas fluorescens & PfB19 & Soil, Puri, Odisha, India & NA \\
\hline 8 & Botryosphaeria ribis & Em63 & Eria meghasinensis orchid leaf & MF373346 \\
\hline 9 & Fusarium oxysporum & Fo02 & C. maxima, Cuttack, Odisha, India & NA \\
\hline 10 & Diaporthe oncostoma & Em71 & Eria meghasinensis orchid stem & MF373351 \\
\hline 11 & Alternaria alternata & $\mathrm{Aa04}$ & C. sativus, Cuttack, Odisha, India & NA \\
\hline 12 & Fusarium solani & $\mathrm{Fs} 01$ & C. maxima, Cuttack, Odisha, India & NA \\
\hline 13 & Oidium heliotropii-indici & Eh03 & Heliotropium indicum, Odisha, India & NA \\
\hline 14 & Candida albicans & Ca15 & C. maxima, Puri, Odisha, India & NA \\
\hline 15 & Trichophyton terrespre & Tt03 & C. maxima, Puri, Odisha, India & NA \\
\hline 16 & Golovinomyces orontii & Cg05 & Coccinia grandis, Nayagarh,Odisha, India & KY319040 \\
\hline 17 & G. orontii & $\mathrm{CgO2}$ & C. grandis, Khordha,Odisha, India & MG646282 \\
\hline 18 & Leveillula taurica & Lt92 & Euphorbia heterophylla, Odisha, India & NA \\
\hline 19 & Oidium heliotropii-indici & Eh03 & Heliotropium indicum & NA \\
\hline 20 & Oidium bonplandiani & Ob93 & Croton bonplandianus & NA \\
\hline 21 & Macrophomina phaseolina & Mpk02 & Mentha arvensis, Lucknow, UP, India & NA \\
\hline
\end{tabular}

accession number in Italics are from other studies

$50 \mathrm{ml}$ sterile distilled water (DW) at four ${ }^{\circ} \mathrm{C}$ with the help of vacuum suction (150 ppm). The samples were purified and subjected to genomic DNA extraction as per the protocol described by Nayak et al. (2019). In the case of test microbes used in this study (Table 2), genomic DNA extraction was carried out as described previously, and the DNA from the cultures reported in the previous study Nayak et al. (2019) were used as test samples for validation of PCR and qPCR assays.

\section{PCR amplification, cloning, and sequencing of rDNA gene cluster}

The rDNA gene cluster, including ITS1, 5.8S and ITS2 regions of selected mildew pathogens listed in Table 1, were subjected to PCR amplification and direct sequencing using Big Dye ${ }^{\mathrm{TM}}$ Terminator v3.1 Cycle Sequencing kit (Applied Biosystems, USA), as described earlier (Nayak et al. 2018). The PCR products of both powdery and downy mildew pathogens such as P. xanthii CsKP07 and $P$. cubensis CsKD11 were then ligated into pGEM-T (Promega, USA) cloning vector according to manufacturer instructions. The clones/plasmids having insert of $P$. xanthii CsKP07 and P. cubensis CsKD11 were labeled as plasmid $C s p 1$ and plasmid $C s d 1$ respectively. The plasmid DNA of both pathogens were isolated and stored at -20 ${ }^{\circ} \mathrm{C}$ for further use.

\section{Species-specific primers design and in silico analysis}

Partial sequences of ITS $1,5.8 \mathrm{~S}$, and ITS 2 regions of $P$. xanthii and $P$. cubensis along with other closely related fungal species of the genus Podosphaera and Pseudoperonospora, were retrieved from GenBank database. Multiple sequence alignment was performed separately for $P$. xanthii and $P$. cubensis pathogens using standalone software program MEGA6 (Tamura et al. 2013). The aligned sequences were visually checked for unique regions having conserved and specific to both $P$. xanthii and P. cubensis. These hallmark regions of both the alignments were subjected to Primer3 v4.1.0 online software (http://primer3.ut.ee) to design species-specific primers for both the pathogens (Untergasser et al. 2012). Thus two sets of candidate primers such as PxK F\&R and PcK F\&R were designed for both pathogens $P$. xanthii and P. cubensis, respectively (Table 3 ). All the primers were evaluated separately for theoretical specificity, and all the parameters such as $\mathrm{G}+\mathrm{C} \%, 3^{\prime}$-self complementarities, hairpin loop, and self dimerization analyzed and custom synthesized (IDT, USA). Besides, Primer-BLAST analysis (https://www.ncbi.nlm.nih.gov/ tools/primer-blast/) was performed for all the designed primers using default parameters. 
Table 3 Oligonucleotide primers designed for development of species-specific PCR and Duplex-qPCR assays.

\begin{tabular}{|c|c|c|c|c|c|c|}
\hline Pathogen & Primers & Sequence $\left(5^{\prime}-3^{\prime}\right)$ & Length & Product size & Annealing temp. $\left({ }^{\circ} \mathrm{C}\right)$ & $\begin{array}{l}\text { Melting } \\
\text { curve peak } \\
\left({ }^{\circ} \mathrm{C}\right)\end{array}$ \\
\hline \multirow[t]{2}{*}{ P. cubensis } & PCKF & GCTGGTTGATTACTGCTTGGCG & 22 & $705 \mathrm{bp}$ & 58 & 88.05 \\
\hline & PCKR & CCGAAGCCACACAACACATAG & 21 & & & \\
\hline \multirow[t]{2}{*}{ P. xanthii } & PXKF & CCCGTGTGAACTCTTATCTG & 20 & $290 \mathrm{bp}$ & & 85.83 \\
\hline & PXKR & GAGGGGTGTTCTGACGCTCG & 20 & & & \\
\hline
\end{tabular}

\section{Specificity and validation of species-specific primers Conventional PCR assay optimization}

The specificity of both the primer sets such as PcK F\&R and PxK F\&R of two mildew pathogens such as P. cubensis and $P$. xanthii, respectively, were validated through conventional PCR assays. Initially, the primer pairs' specificity was tested against the corresponding mildew isolates (Table 1). Subsequently, these assays were tested against non-mildew pathogens, includes Alternaria spp., Aspergillus spp., Penicillium spp., Cladosporium spp., Botrytis spp. etc. (Table 2). PCR was conducted in a $25 \mu \mathrm{l}$ volume containing $12.5 \mu \mathrm{l}$ of PCR master mix (Promega, USA), two $\mu \mathrm{l}$ of template DNA ( $20 \mathrm{ng}), 0.5 \mu \mathrm{l}$ of each forward and reverse primers $\left(10 \mu \mathrm{mol}^{-1}\right.$ each), and nuclease-free water to make up the volume. The PCR amplifications were conducted with an initial denaturation at $94{ }^{\circ} \mathrm{C} 7 \mathrm{~min}$, followed by 35 cycles of $30 \mathrm{~s}$ at $94{ }^{\circ} \mathrm{C}$, $30 \mathrm{~s}$ at $58{ }^{\circ} \mathrm{C}$ and $1 \mathrm{~min}$ at $72{ }^{\circ} \mathrm{C}$ and a final extension of 10 min at $72{ }^{\circ} \mathrm{C}$. The DNA from healthy cucurbit plants and non-DNA template samples were used as negative controls. All the PCR products were analyzed on a $1.2 \%$ agarose gel along with a $1 \mathrm{~kb}$ DNA ladder (Thermo Fisher Scientific, India). All the experiments were repeated three times with three independent samples.

High-resolution melting (HRM) analysis and primer specificity evaluation Real-time PCR validation of speciesspecific primers was performed using a 7500 Fast Dx real-time PCR instrument with SDS software (Applied Biosystems, USA). The reaction mix contained $12.5 \mu \mathrm{l}$ of Maxima SYBR Green/ROX qPCR Master Mix $(2 \times)$ (Thermo Scientific, USA) $400 \mathrm{nM}$ of each primer, $20 \mathrm{ng}$ of DNA template of each mildew isolate and nuclease-free water to reach a final volume of $25 \mu \mathrm{l}$. No template controls (NTC) were systematically included in triplicate. The thermal cycling conditions comprised an initial denaturation step of $7 \mathrm{~min}$ at $95^{\circ} \mathrm{C}$ for $30 \mathrm{~s}$ and annealing at $60{ }^{\circ} \mathrm{C}$ for the $30 \mathrm{~s}$. A melt curve analysis using a temperature gradient from $60^{\circ} \mathrm{C}$ to $100^{\circ} \mathrm{C}$ and a ramp speed of $0.5^{\circ} \mathrm{C} / \mathrm{s}$ and continuous fluorescent measurement was performed after the last cycle.

Species-specific qPCR assay performed, DNA isolated from pure cultures of both the mildew isolates
CsKP07 and CsKD11, used as the positive control. Reactions containing DNA from healthy cucurbit plants and NTC reactions were used as negative controls. All qPCR assays were performed in triplicate. The expected size of both the mildew pathogens was confirmed by gel electrophoresis, as described above.

\section{Optimization of specific PCR assays under duplex PCR mode}

For the duplex PCR assay, the annealing temperature of both the designed primer sets was optimized through gradient PCR. The duplex PCR was conducted in a $25 \mu \mathrm{l}$ volume containing $12.5 \mu \mathrm{l}$ of Platinum ${ }^{\circledR}$ Multiplex PCR master mix (2X)(Applied biosystems, USA), and reaction conditions were conducted as described in simplex PCR, except optimization of annealing temperature $\left(58{ }^{\circ} \mathrm{C}\right)$, the concentration of the primer $(2.5 \mathrm{pmol})$, and $0.5 \mu \mathrm{l}$ template DNA. Duplex PCR products were analyzed on a $1.2 \%$ agarose gel with $1 \mathrm{~kb}$ ladder. All the experiments were repeated three times with three independent samples.

\section{The sensitivity of $q P C R$ assays and standard curve preparation}

The sensitivity or limit of detection of species-specific primers under the duplex qPCR assay was determined by using the plasmid DNA obtained from $C s p 1$ and $C s d 1$ plasmids of both the mildew pathogens $P$. xanthii CsKP07 and P. cubensis CsKD11 respectively were prepared as mentioned earlier. The initial plasmid DNA concentration was adjusted to $100 \mathrm{ng} / \mu \mathrm{l}$ by using a NanoDrop $^{\text {TM }} 1000$ spectrophotometer (Thermo Fisher Scientific, USA) and then serially diluted tenfold wise (1:10). The ten-fold serially diluted DNA was used as a target for the SYBR green-based qPCR, and thermal cycling conditions were followed as described above. A standard curve was drawn with linear regression between $\mathrm{Ct}$ and the $\log$ value of DNA concentration (Bandamaravuri et al. 2015). Appropriate negative controls were maintained; all the experiments were performed three times, and technical replicates maintained. 


\section{Detection of $P$. cubensis and $P$. xanthii from plant materials and soil samples}

The species-specific duplex-PCR and qPCR assays were evaluated for the detection of targeted pathogens from plant and soil samples collected from different cucurbit fields (Table 4). Detection of both the pathogens was performed in both conventional PCR and qPCR assay under the duplex mode, as described above. Relative quantification of target pathogens was estimated through a standard curve derived between the linear regression of $\mathrm{Ct}$ and the log value of DNA concentrations. All these assays were analyzed in triplicate reaction.

\section{Results}

Specificity and validation of species-specific primers

Initially, the specific primer sets such as PxK F\&R and PcK F\&R (Table 3) tested against their corresponding pathogens, and single monomorphic bands at $\sim 290 \mathrm{bp}$ and $\sim 705$ bp were obtained from $P$. xanthii and $P$. cubensis, respectively. Further, these species-specific primers or assays investigated against different test microbes obtained from different sources (Table 2). None of the test microbes showed amplification with the species-specific primers such as PxK F\&R and PcK F\&R (Fig. 1).

Both the species-specific PCR primer pairs (PcK F\&R and PxK F\&R) validated under individual PCR assays, as mentioned above, were subjected for validation under duplex PCR assay mode. The specificity of the duplex PCR assay was evaluated against different test microbial isolates as mentioned in Table 2, including the test microbes used in the Nayak et al. (2019) and genomic DNA obtained from dually infected cucumber (P. cubensis CsKD11 and P. xanthii CsKP07) leaf samples (Table 4) was used as a positive control. The duplex PCR assay showed amplification only in positive samples with two distinctly separated specific bands of $\sim 705$ bp and $\sim 290$ bp (Figs. 1, 2), and no amplification observed in test samples (Table 2).

Table 4 Detection of downy mildew and powdery mildew pathogens in different field and environmental samples

\begin{tabular}{|c|c|c|c|c|c|}
\hline \multirow[t]{2}{*}{ SI. no. } & \multirow[t]{2}{*}{ DNA sample description } & \multicolumn{2}{|c|}{ Duplex-PCR } & \multicolumn{2}{|c|}{ Duplex-qPCR and HRM analysis } \\
\hline & & P. xanthii & P. cubensis & $\begin{array}{l}\text { P. xanthii } \\
\text { Conc. in } n g /\left.\mu\right|^{\mathrm{a}} / \\
\left(85.83^{\circ} \mathrm{C}\right)\end{array}$ & $\begin{array}{l}\text { P. cubensis } \\
\text { Conc. in ng/ } \\
\mu \mathrm{I}^{\mathrm{a} /(88.05} \\
\left.{ }^{\circ} \mathrm{C}\right)\end{array}$ \\
\hline 1 & Infected C. sativus leaf & + & + & $1 /(\sqrt{ })$ & $0.1 /(\sqrt{ })$ \\
\hline 2 & C. maxima leaf & + & - & $0.15 /(\sqrt{ })$ & $-/(-)$ \\
\hline 3 & M. charantia leaf, and stem & + & + & $0.20 /(\sqrt{ })$ & $0.1 /(\sqrt{ })$ \\
\hline 4 & L. cylindrica, leaf & + & + & $0.7 /(\sqrt{ })$ & $0.5 /(\sqrt{ })$ \\
\hline 5 & L. acutangula, leaf & - & + & $-/(-)$ & $0.5 /(\sqrt{ })$ \\
\hline 6 & C. grandis, leaf, and stem & - & - & $-/(-)$ & $-/(-)$ \\
\hline 7 & C. melo, leaf & + & + & $0.2 /(\sqrt{ })$ & $0.1 /(\sqrt{ })$ \\
\hline 8 & Surface soil from cucumber cultivating field & + & + & $0.005 /(\sqrt{ })$ & $0.02 /(\sqrt{ })$ \\
\hline 9 & Seedlings of $C$. sativus & - & + & $-/(-)$ & $0.5 /(\sqrt{ })$ \\
\hline 10 & Infected L. siceraria dry, and fallen leaves & - & + & $-/(-)$ & $0.001 /(\sqrt{ })$ \\
\hline
\end{tabular}

Duplex PCR indicating +-amplification, --no amplification

${ }^{a}$ Relative quantification of target pathogens. $(\sqrt{ })$-Presence of signature peak and (-)-absence of peak in HRM analysis

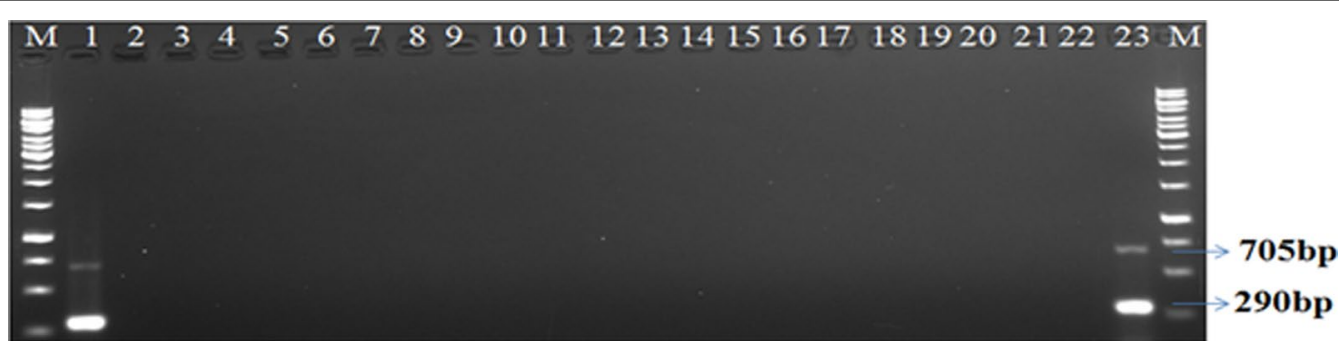

Fig. 1 Validation of species-specific duplex PCR assay: Lane 1 and 23 indicate PCR amplified products of $\sim 705$ bp and $\sim 290$ bp from the genomic DNA of $P$. cubensis and P. xanthii isolates. Lane 2-22 represents test microbes listed in Table 2. M: 1 kb ladder 


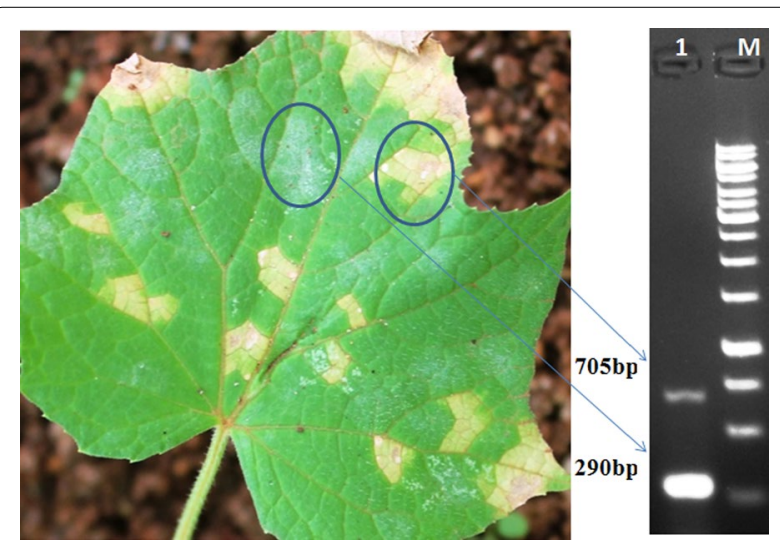

Fig. 2 Illustration of species-specific duplex PCR assay: downy mildew and powdery mildew infection on Cucumis sativus leaf and gel picture (depicted from Fig. 1) indicating simultaneous detection of $P$. cubensis and P.xanthii

\section{Real-time PCR HRM analysis}

The HRM analysis of both P. cubensis and P. xanthii was performed by using the genomic DNA of the respective pathogens (Table 1 ). The $P$. cubensis specific primers (PcK F\&R) under SYBR green qPCR through HRM analysis produced a single peak at melting temperature (Tm) value of $88.05{ }^{\circ} \mathrm{C}$ (Fig. 3a). In the case of P. xanthii, specific primer (PxK F\&R), the HRM analysis produced a single peak at a Tm value of $85.83{ }^{\circ} \mathrm{C}$ (Fig. 3b). In both assays, no amplification observed from the NTCs (no template control) and negative controls.

In the case of HRM analysis for a duplex qPCR assay, both the species-specific primers (PcK F\&R and PxK $F \& R$ ) and assay conditions were optimized for SYBR green qPCR format. The duplex HRM assay was performed using the genomic DNA of dually infected leaf samples (Table 4). The duplex HRM assay showed two separate melting peaks at Tm values of $85.8{ }^{\circ} \mathrm{C}$, and 88.0 ${ }^{\circ} \mathrm{C}$ (Fig. 4), and the NTCs and negative control showed no amplification peaks.

The specificity of both simplex and duplex assays under HRM analysis determined by observing no fluorescent peak signals exceeding the baseline threshold and nonspecific bands from different test microbes (Table 2). All the experiments performed in triplicate.

Standard curves for both pathogens with the corresponding primer pair generated for evaluation of sensitivity or detection limit of each primer set under qPCR assay. Serial dilutions of the plasmid DNA of both pathogens provided a linear range of the standard curve between $\mathrm{Ct}$ value and the log of DNA concentration. The standard curve revealed that the PxK F\&R primer set ( $P$. xanthii) revealed a linear slope of -1.757 and a regression coefficient $\left(R^{2}\right)=0.9936$ with an amplification efficiency of $99 \%$ (Fig. 5). Similarly,

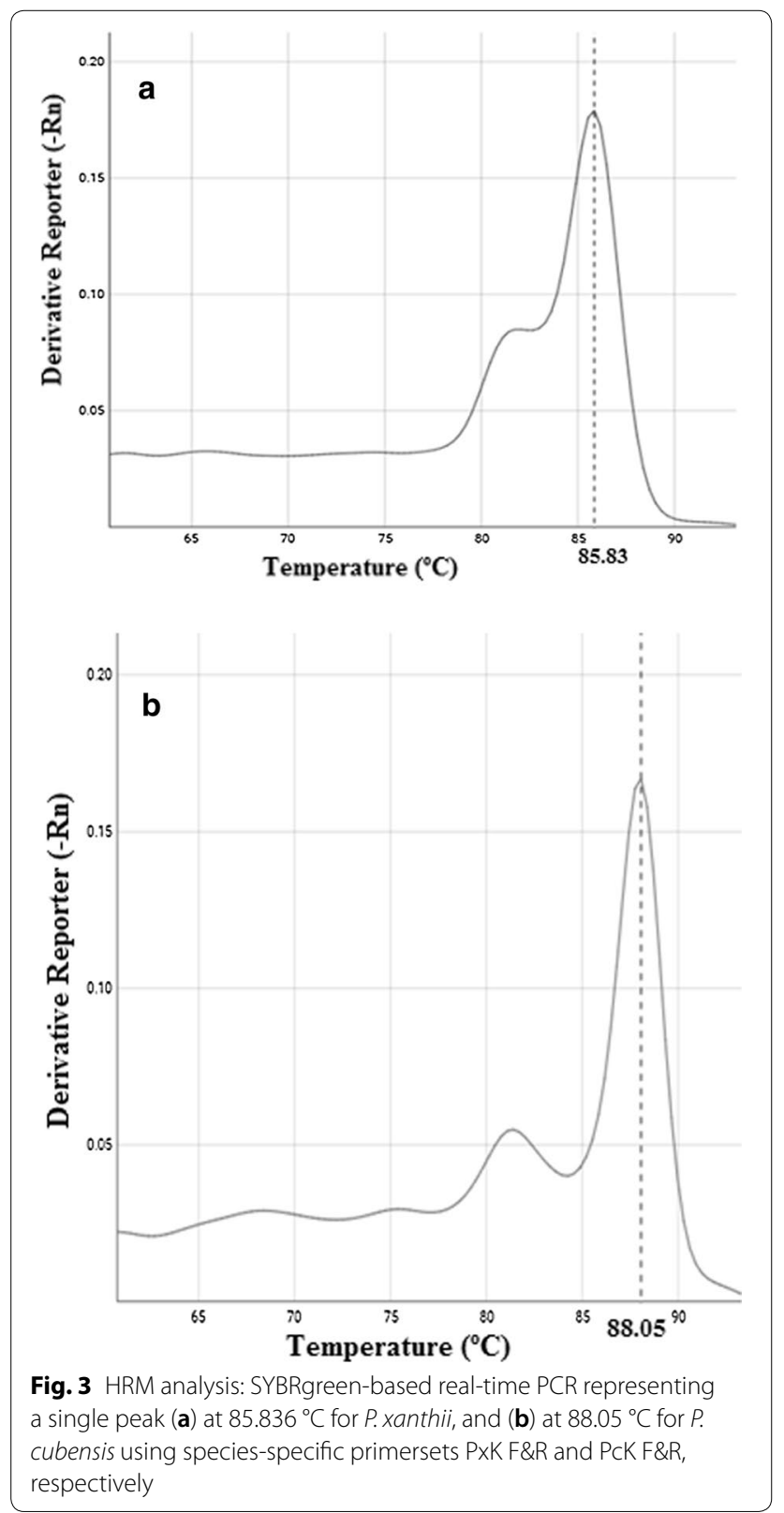

in the case of $P$. cubensis, the standard curve between $\mathrm{Ct}$ and DNA concentration revealed a slope of -1.961 and $R^{2}=0.9983$ and the amplification efficiency of PcK F\&R primer set recorded as 99\% (Fig. 6). The least detection of the target using the plasmid DNA of Csp1 (P. xanthii) and $C s d 1$ (P. cubensis) estimated at $0.1 \mathrm{pg} / \mu \mathrm{l}$, at $\mathrm{Ct}$ values around 34 and 35 , respectively (Figs. 5, 6).

\section{Detection of $P$. cubensis and $P$. xanthii from the plant material and soil samples}

Under optimized conditions, the SYBR green-based qPCR assay showed standard fluorescence amplification 


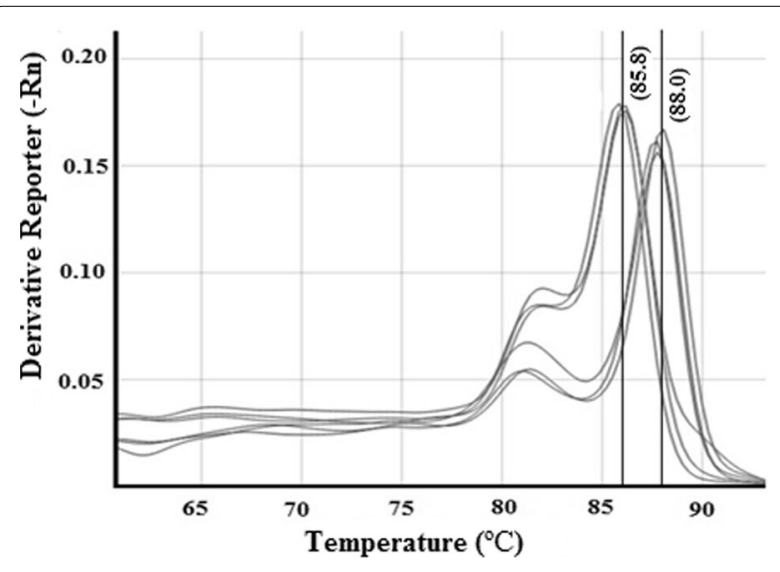

Fig. 4 HRM analysis of duplex qPCR assay indicating two specific signature peaks at $85.8^{\circ} \mathrm{C}$ for P.xanthii and $88.0^{\circ} \mathrm{C}$ for P. cubensis

for both mildew pathogens in a separate assay representing exponential growth of PCR products, and standard curves obtained as described above. The HRM analysis of plant materials from C. sativus, M. charantia, L. cylindrica, C. melo, and surface soil samples from cucumber cultivating field showed two separate peaks at Tm value $85.8{ }^{\circ} \mathrm{C}$ and $88{ }^{\circ} \mathrm{C}$, which represented the presence of dual infection of both pathogens such as $P$. xanthii and $P$. cubensis. While, the plant materials obtained from $C$. maxima, $L$. acutangula, $L$. siceraria, and seedlings of $C$. sativus showed a single peak as an indication of presence of a single pathogen. The relative quantification of the pathogens in each sample estimated through qPCR assay. The duplex PCR assay also provided similar results
(Fig. 7), as indicated by HRM analysis. The plant materials of C. grandis showed no amplification in both PCR and qPCR assays (Table 4).

\section{Discussion}

Pseudoperonospora cubensis and $P$. xanthii pathogens are devastating in nature with a broad host range of cucurbits and also challenging to identify by morphological, biochemical features, which are similar to many obligate pathogens (Lee et al. 2016). However, before taking any intervening control measures, it is vital to obtain an accurate picture of the phytosanitary situation (Wyenandt et al. 2015). Sometimes all cucurbit vegetables during the vegetative season can be easily confused with the disease symptoms; in some cases, both the mildew pathogens are infecting simultaneously on several cucurbits include gourds, melon, and pumpkin during favorable conditions and making it difficult to distinguish both the pathogens based on morphological symptoms particularly during early infection (Wallace et al. 2015). A rapid and reliable assay for detection and discrimination of $P$. cubensis and $P$. xanthii from field and plant material could be a prerequisite. Further, the powdery mildew disease caused by two different obligate fungal pathogens such as G. orontii and $P$. xanthii sharing common cucurbit hosts and showing similar disease symptoms, which made cucurbit powdery mildew disease more complex and challenging for disease-resistant varietal screening. To address this challenge, the current study developed a novel, sensitive and rapid duplex PCR assay and HRM analysis for simultaneous detection and quantification of $P$. cubensis and P. xanthii pathogens from different cucurbit crops (Table 1).

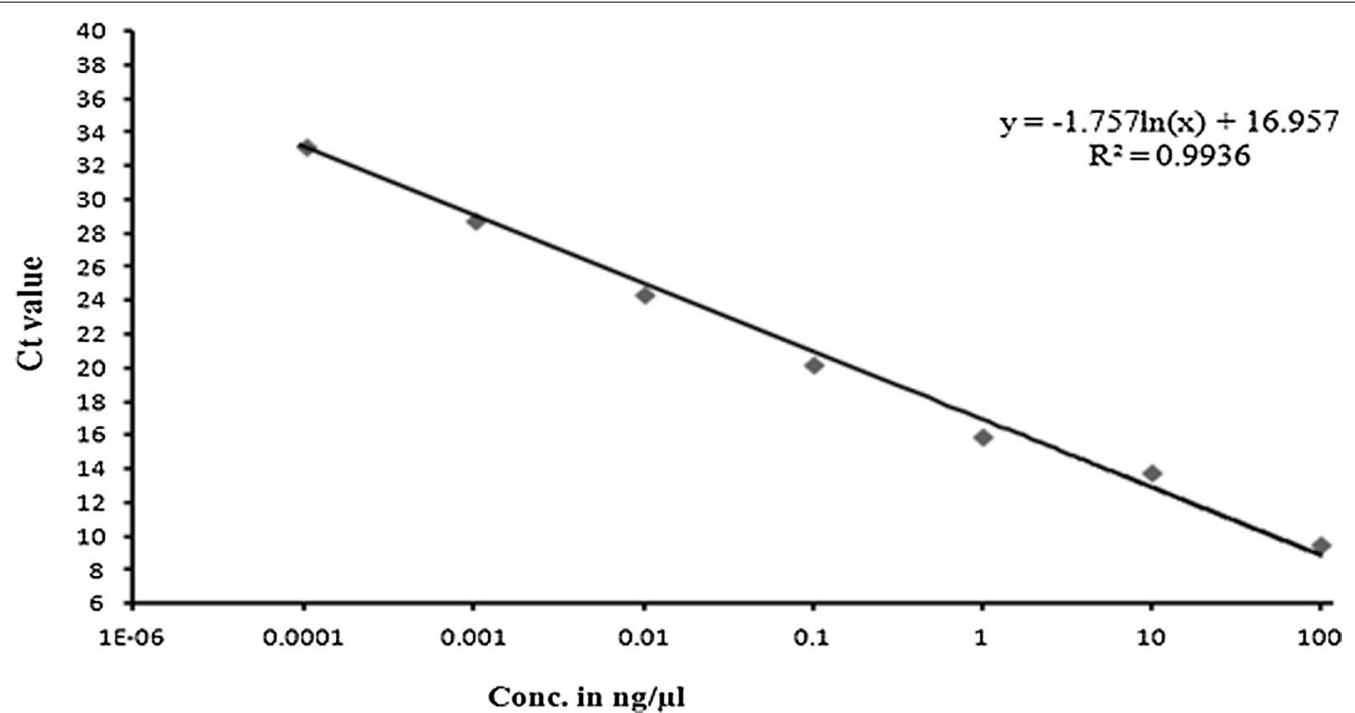

Fig. 5 A standard curve indicating the limit of detection of P.xanthii species-specific qPCR assay obtained from 10-fold dilution of plasmid (Csp 1) DNA 


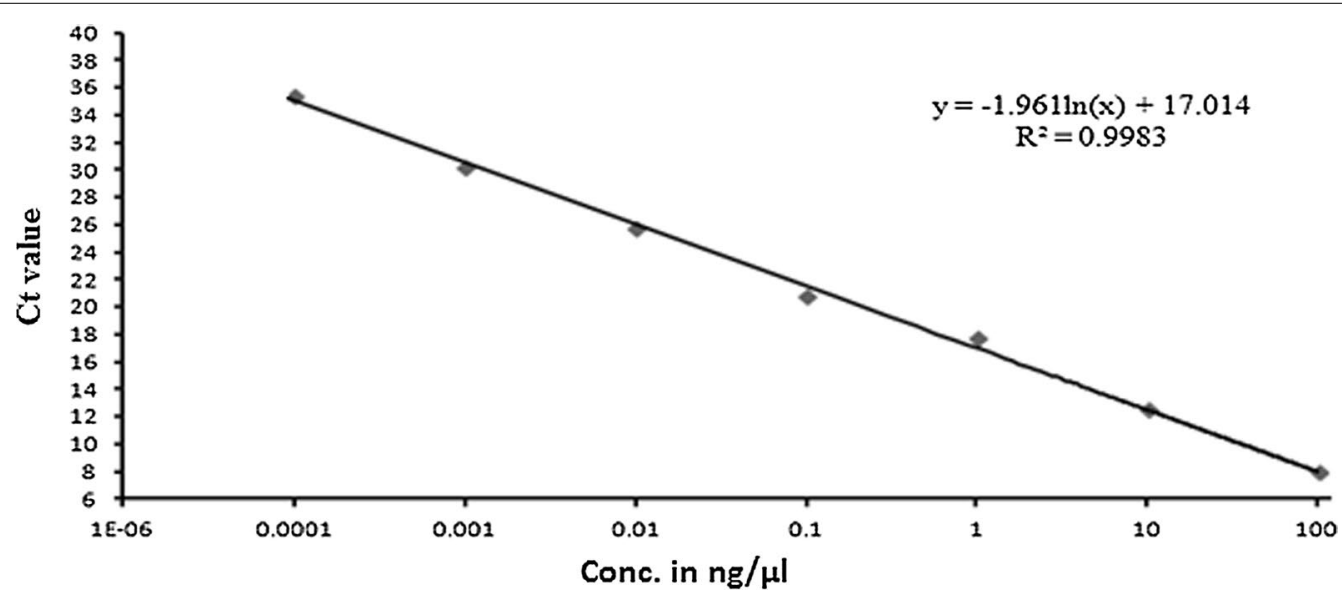

Fig.6 Limit of detection of P. cubensis specific qPCR assay, the standard curve derived from the 10-fold diluted plasmid (Csd1) DNA

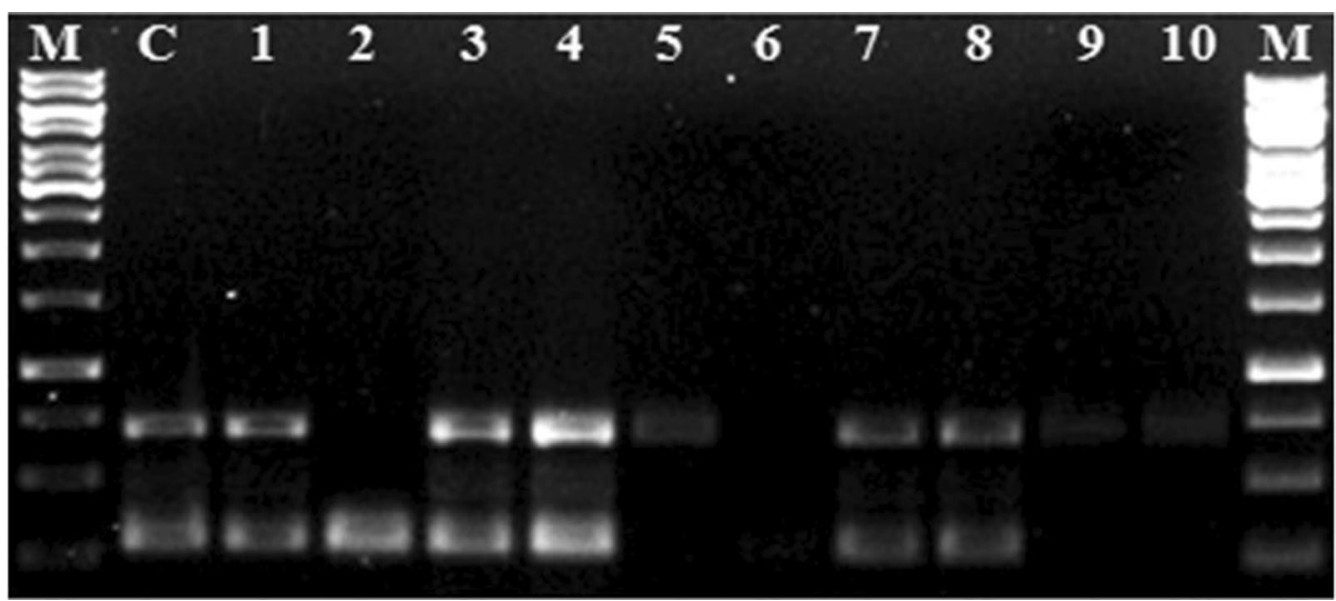

Fig.7 Evaluation of duplex PCR assay for field and environmental samples: Lane 1-10 represents different field samples listed in the Table 4. Lane C represents positive control for duplex PCR and M represents $1 \mathrm{~kb}$ ladder

A reliable duplex PCR assay depends on the design and use of the primers specific to the intended target pathogen. In the current study, the species-specific primers for both the pathogens initially targeted on three prominent loci of the rDNA gene cluster, such as $28 \mathrm{~S}, 18 \mathrm{~S}$, and ITS regions. Later the multiple sequence alignment of the ITS region of different species of Erysiphales and Peronosporales, closely related to both pathogens $P$. xanthii and $P$. cubensis, were found to have significant interspecies variations, which are suitable for the design of species-specific primers. The ITS region of the rDNA gene cluster has established as a suitable target for fungal species-specific primers due to their high copy number, sequence variability, and fidelity among pathogen species or subspecies. Several researchers reported that the identification of obligate fungi causing powdery mildew and downy mildew diseases by developing species-specific primers targeted on ITS region of rDNA (Wang et al. 2008; Pirondi et al. 2015; Bandamaravuri et al. 2015; Lee et al. 2016; Nayak et al. 2019).

In some cases, the sequence variations in the ITS region between closely related species are not always sufficient to define highly specific primers due to SNP variations (Choi et al. 2005; Lee et al. 2016). In recent studies, the transcriptome based species-specific genes targeted to enhance the specificity of the molecular detection assays (Rahman et al. 2019; Withers et al. 2016). In this study, two species-specific primer sets designed for both P. cubensis (PcK F\&R) and P. xanthii (PxK F\&R) targeting 
the ITS region of rDNA cluster. The specificity of both the primer sets was demonstrated by the specific amplification of $\sim 705 \mathrm{bp}$ and $\sim 290 \mathrm{bp}$ fragments from $P$. cubensis and $P$. xanthii using specific primers PcK F\&R and PxK $F \& R$, respectively. PCR amplification was not observed in non-target DNA samples and other closely related test microbes (Table 2), which indicated the specificity of both species-specific oligonucleotide primer sets.

Similarly, under the optimized parameters, the duplex PCR assay with PcK F\&R and PxK F\&R primer sets provided two distinctly separated PCR products of the expected size (Fig. 1). Both the specific primer sets were used separately in conventional PCR assays to evaluate their specificity. For estimation of detection limit and sensitivity of both the primer sets, validated through simplex and duplex PCR under SYBR green qPCR assay (Mackay et al. 2002). Further, the duplex qPCR assay successfully detected both pathogens $P$. cubensis and $P$. xanthii from different plant materials and soil samples obtained from cucurbit (Table 4). Thus the conventional and duplex PCR assay could be used to identify both pathogens from a complex microbial community other than plant-parasitic or obligate pathogens. The developed assays simultaneously detected and identified both pathogens directly from the DNA of leaf, stem, and field samples. The duplex PCR assay is suitable for detecting the fungal pathogen present in leaf or stem part of plants with or without symptoms (Figs. 2, 7). This assay could also be used to quantify the pathogen load and monitor the survival and spread of both pathogens at the early stage of disease development (Mercado et al. 2003; Rahman et al. 2017). This assay could get insights of disease epidemiology and of the disease, thereby used as a development of effective strategies for controlling diseases.

In recent studies, the HRM technique is being used for the rapid, accurate identification and discriminating between closely related pathogens in clinical biology and food microbiology fields of the study around the world (Kagkli et al. 2012). The advantages of this assay are higher sensitivity and better specificity, and the ability to quantify target pathogens from field samples. Compared with conventional PCR techniques, qPCR provides immediate results that are expressed with quantitative value, without the need for agarose gel electrophoresis. The HRM assay targeted on single-nucleotide variations at ITS and $\operatorname{cox} 2$ regions was developed to differentiate between two closely related cucurbit downy mildew pathogens P. cubensis and P. humuli (Summers et al. 2015; Lee et al. 2016). In the current study, though $P$. humuli was not used as a target in the detection assays, the other closely related and regionally important fungal pathogens were tested to evaluate the duplex qPCR assay specificity. The high resolution melting peaks in single and duplex
HRM analysis stated about the primer specificity and also discriminate between $P$. cubensis and $P$. xanthii pathogens simultaneously. This assay also exhibited high efficiency and with the ability to identify as low as $0.1 \mathrm{pg} / \mu \mathrm{l}$ of the target DNA.

In conclusion, the optimized qPCR with HRM analysis is highly essential for detection or discrimination of both the target pathogens and also from other closely related pathogens even from a very fewer quantity of sample material. The species-specific primers designed and used in this study were specific and reliable for the detection and identification of both pathogens over simplex and duplex reaction setup. Also they provided a robust and rapid domino effect under both conventional and qPCR assay formats.

\section{Acknowledgements}

The authors are thankful to the Director, CSIR-CIMAP, Lucknow, India for providing all necessary facilities during the study and the Chief Executive, Regional Plant Resource Centre, Odisha, India for providing grant and supporting AN during his doctoral program, as a part of this investigation. This manuscript obtained institutional approval under reference no: 2019 NOV99.

\section{Authors' contributions}

$\mathrm{KB}$ and $\mathrm{AN}$ contributed for planning, experimentation, field observations, sample collection and data analysis. $A B$ and $A N$ conducted experiments and result analysis of qPCR assays. KB and AS wrote the manuscript. All authors read and approved the final manuscript.

\section{Funding}

Not applicable.

\section{Availability of data and materials}

The data supporting the results of this research work are included within the article. Data and materials including specimens and genetic material of obligate fungi, can be requested from the corresponding author.

Ethics approval and consent to participate:

Not applicable.

\section{Consent for publication}

Not applicable.

\section{Competing interests}

The authors declare that they have no conflict of interest.

\section{Author details}

${ }^{1}$ Department of Plant Pathology, Crop Protection Division, CSIR-Central Institute of Medicinal and Aromatic Plants, Lucknow 226015, India. ${ }^{2}$ Department of Microbial Technology, Crop Protection Division, CSIR-Central Institute of Medicinal and Aromatic Plants, Lucknow 226015, India. ${ }^{3}$ Microbial Genomics and Diagnostics Lab, Plant Pathology and Microbiology Division, Regional Plant Resource Centre, Bhubaneswar, Odisha 751015, India.

Received: 16 January 2020 Accepted: 22 July 2020

Published online: 03 August 2020

\footnotetext{
References

Afari C, Koffuor GA, Duah P (2012) The effect of Cucumis sativus L. and Cucumbita pepo L. (Cucurbitaceae) aqueous preparations on galactose induced cataract in Sprague-Dawley rats. Int Res J Pharm 2:174-180

Bandamaravuri KB, Sharma R (2015) Taq Man real-Time PCR assay for the detection and quantification of Sclerospora graminicola, the causal agent of pearl millet downy mildew. Eur J Plant Pathol 142:149-158
} 
Bi X, Hieno A, Otsubo K, Kageyama K, Liu G, Li M (2019) A multiplex PCR assay for three pathogenic Phytophthora species related to kiwifruit diseases in China. J Gen Plant Pathol 85:12-22

Bown D (1995) Encyclopaedia of Herbs and their Uses. Dorling Kindersley, London

Chamberlain JS, Gibbs RA, Ranier J, Nguyen PN, Caskey T (1988) Deletion screening of the Duchenne muscular dystrophy locus via multiplex DNA amplification. Nucleic Acids Res 16:11141-11156

Choi YJ, Hong SB, Shin HD (2005) A re-consideration of Pseudoperonospora cubensis and P. humuli based on molecular and morphological data. Mycol Res 109:841-848

Colucci SJ, Wehner TC, Holmes GJ (2006) The downy mildew epidemic of 2004 and 2005 in the Eastern United States. In: Holmes GJ, ed. Proceedings of cucurbitaceae. Universal Press, Raleigh. pp\&nbsp;403-411

Falacy JS, Grove GG, Mahaffee WF, Galloway H, Glawe DA, Larsen RC, Vandermark GJ (2007) Detection of Erysiphe necator in air samples using the polymerase chain reaction and species-specific primers. Phytopathology 97:1290-1297

Gachon C, Mingam A, Charrier B (2004) Real-time PCR: What relevance to plant studies? J Exp Bot 55:1445-1454

Goker M, Voglmayr H, Riethmüller A, Weiß M, Oberwinkler F (2003) Taxonomic aspects of Peronosporaceae inferred from Bayesian molecular phylogenetics. Can J Bot 81:672-683

Hollomon D, Wheeler IE (2002) Controlling powdery mildews with chemistry. In: Bélanger RR, Bushnell WR, Dik AJ, Carver TLW (eds) The powdery mildews: a comprehensive treatise. The American Phytopathological Society, St. Paul, pp\&nbsp;249-255

Holmes G, Ojiambo PS, Hausbeck M, Quesada-Ocampo LM, Keinath AP (2015) Resurgence of cucurbit downy mildew in the United States: A watershed event for research and extension. Plant Dis 99:428-441

loos R, Fourrier C, Wilson V, Webb K, Schereffer JL, Tourvielle de LD (2012) An optimised duplex real-time PCR tool for sensitive detection of the quarantine oomycete Plasmopara halstedii in sunflower seeds. Phytopathology 102:908-917

Judd WS, Campbell CS, Kellogg EA, Stevens PF, Donoghue MJ (2008) Plant systematics-a phylogenetic approach. Sinauer Associates, Inc. Sunderland, Massachusetts.

Kagkli DM, Folloni S, Barbau-Piednoir E, Van den Eede G, Van den Bulcke M (2012) Towards a pathogenic Escherichia coli detection platform using multiplex SYBR ${ }^{\circledR}$ Green Real-time PCR methods and high resolution melting analysis. PLoS One 7:387-392

Kaushik U, Aeri V, Mir SR (2015) Cucurbitacins_-an insight into medicinal leads from nature. Pharmacogn Rev 9:12-18

Kiss $L$ (2003) A review of fungal antagonists of powdery mildews and their potential as biocontrol agents. Pest Manag Sci 59:475-483

Lebeda A, Cohen Y (2011) Cucurbit downy mildew (Pseudoperonospora cubensis): biology, ecology, epidemiology, host-pathogen interaction and control. Eur J Plant Pathol 129:157-159

Lebeda A, Urban J (2004) Distribution, harmfulness and pathogenic variability of cucurbit downy mildew in the Czech Republic. Acta fytotechn zootechn 7:170-173

Lee JH, Park MH, Lee S (2016) Identification of Pseudoperonospora cubensis using real-time PCR and high resolution melting (HRM) analysis. J Gen Plant Pathol 82:110-115

Mackay IM, Arden KE, Nitsche A (2002) Real-time PCR in virology. Nucleic Acids Res 30:1292-1305

Mercado BJ, Rodríguez JD, Parrilla AS, Jiménez DRM (2003) Simultaneous detection of the defoliating and non-defoliating Verticillium dahliae pathotypes in infected olive plants by duplex, nested polymerase chain reaction. Plant Dis 87:1487-1494

Nayak AK, Bandamaravuri KB (2019) Detection of Golovinomyces orontii using species-specific primers and high-resolution melting analysis. Trop plant pathol 44:343-351

Nayak AK, Mund NK, Bandamaravuri KB (2018) Identification of powdery mildew disease on Cleome rutidosperma caused by Podosphaera xanthii in Odisha, India. Indian Phytopathol 71:627-629

Olczak-Woltman H, Marcinkowska J, Niemirowicz-Szczytt K (2011) The genetic basis of resistance to downy mildew in Cucumis spp. latest developments and prospects. J Appl Genet 52:249-255
Pirondi A, Pérez-García A, Battistini G, Muzzi E, Brunelli A, Collina M (2015) Seasonal variations in the occurrence of Golovinomyces orontii and Podosphaera xanthii, causal agents of cucurbit powdery mildew in northern Italy. Ann Appl Biol 167:298-313

Rahman A, Miles TD, Martin FN, Quesada-Ocampo LM (2017) Molecular approaches for biosurveillance of the cucurbit downy mildew pathogen, Pseudoperonospora cubensis. Can J Plant Pathol 39:282-296

Rahman A, Góngora-C E, Bowman MJ, Childs KL, Gent DH, Martin FN, Quesada-Ocampo LM (2019) Genome sequencing and transcriptome analysis of the hop downy mildew pathogen Pseudoperonospora humuli reveal species-specific genes for molecular detection. Phytopathology 109:1354-1366

Savory EA, Granke LL, Quesada-Ocampo LM, Varbanova M, Hausbeck MK, Day B (2011) The cucurbit downy mildew pathogen Pseudoperonospora cubensis. Mol Plant Pathol 12:217-226

Schenck N, Fourrier-Jeandel C, loos R (2016) A robust and specific real-time PCR tool for the detection of Phytophthora lateralis in plant tissues. Eur J Plant Pathol 146:231-244

Shishkoff N (2000) The name of the cucurbit powdery mildew: Podosphaera (sect. Sphaerotheca) xanthii (Castag) U Braun \& N Shish comb nov. Phytopathology 90:133

Sitterly WR (1978) Powdery Mildew of Cucurbits. In: Spencer DM (ed) The Powdery Mildews. Academic Press Inc. Ltd., London, pp 359-379

Summers CF, Adair NL, Gent DH, McGrath MT, Smart CD (2015) Pseudoperonospora cubensis and $P$. humuli detection using species-specific probes and high definition melt curve analysis. Can J Plant Pathol 37:315-330

Tamura K, Stecher G, Peterson D, Filipski A, Kumar S (2013) MEGA6: Molecular Evolutionary Genetics Analysis Version 6.0. Mol Biol Evol 30:2725-2729

Thomas CE (1996) Downy mildew. Compendium of cucurbit diseases. Zitter TA, Hopkins DL, ThomasCE (eds) APS Press, St. Paul pp\&nbsp;24-26

Untergasser A, Cutcutache I, Koressaar T, Ye J, Faircloth BC, Remm M, Rozen SG (2012) Primer3 - new capabilities and interfaces. Nucleic Acids Res 40(15):e115

Waard MA, Georgopoulos SG, Hollomon DW, Ishii H, Leroux P, Ragsdale NN, Schwinn FJ (1993) Chemical control of plant disease: problems and prospects. Annu Rev Phytopathol 31:403-421

Wallace EC, Adams M, Quesada-Ocampo LM (2015) First report of downy mildew on buffalo gourd (Cucurbita foetidissima) caused by Pseudoperonospora cubensis in North Carolina. Plant Dis 99:1861

Wang N, Ma Y, Yang C, Dai G, Wang Z (2008) rDNA-ITS sequence analysis of pathogens of cucumber downy mildew and cucumber powdery mildew. Front Agric China 2:317-320

Waterhouse G, Brothers M (1981) The taxonomy of Pseudoperonospora cubensis. Mycological Papers 148:1-28

Watson A, Napier T (2009) Disease of cucurbit vegetables. Primefacts 832:1-6. https://www.dpi.nsw.gov.au/_data/assets/pdf_file/0003/290244/disea ses-of-cucurbit-vegetables.pdf

Withers S, Gongora-Castillo E, Gent D, Thomas A, Ojiambo PS, QuesadaOcampo LM (2016) Using next-generation sequencing to develop molecular diagnostics for Pseudoperonospora cubensis the cucurbit downy mildew pathogen. Phytopathology 106:1105-1116

Wyenandt CA, Simon JE, Pyne RM, Homa K, McGrath MT, Zhang S, Raid RN, Ma LJ, Wick R, Guo L, Madeiras A (2015) Basil downy mildew (Peronospora belbahrii): Discoveries and challenges relative to its control. Phytopathology 105:885-894

Zambounis A, Ganopoulos I, Chatzidimopoulos M, Tsaftaris A, Madesis P (2015) High-resolution melting approaches towards plant fungal molecular diagnostics. Phytoparasitica 43:265-272

Zitter TA, Hopkins DL, Thomas CE (1996) Compendium of cucurbit diseases. APS Press, St. Paul

\section{Publisher's Note}

Springer Nature remains neutral with regard to jurisdictional claims in published maps and institutional affiliations. 